\title{
Rhythm and Polystylistic Rock Music
}

\author{
Yvetta Kajanová
}

Rock, being a musical genre with more than fifty years' history in the music culture of the twentieth century, is largely based on previous developments in jazz, blues, and country and western music. It has adopted elements from them and adjusted them to the new musical mind of rock musicians. The question arises to what extent this musical mind differs from the preceding tendencies in jazz.

The basis for our study was found in the assumption of jazz theoretician Joachim Ernst Berendt, who in Das Jazzbuch ${ }^{91}$ speaks about specific characteristics of jazz evident in special tone creation, usage of improvisation and typical jazz rhythm. We used these elements to examine rhythm in particular rock styles.

The most obvious resemblance to jazz, blues, country and western and rock music may be found in rhythm, where rock musicians work with rhythmical models - patterns. Unlike jazz, however, the rock patterns are marked by the essence of urban music culture, accenting the "hardness" of the times. Distinct from European classical music, both genres, jazz and rock, accentuate either the second and the fourth beat, or the third beat, while the remaining beats are off beat. ${ }^{92}$ The main difference between the jazz and rock rhythm consists in the so-called "shuffle rhythm", where the particular beats, written down in equal values (e.g. eight notes in 4/4 metre) are performed in jazz with slight shifts, deviations realized by the performer, thus adding a feeling of relaxation - negligence, relaxedness, ease - to the rhythm. Conversely, the rock musician accentuates the given beats pregnantly and rhythmically accurately, not off beat like jazzmen, while the main pulse stresses either the second and fourth beat, or the first and third one. The existence of rhythmical patterns and polyrhythms is typical of both genres, jazz and rock. For the

91 Joachim Ernst Berendt, Kniha o jazze [Book about Jazz] (Bratislava, 1968, first edition in 1953); Joachim Ernst Berendt, Das Jazzbuch. Entwicklung und Bedeutung des Jazzmusik (Frankfurt, 1953); Das Jazzbuch. Von Rag bis Rock (Frankfurt, 1973).

92 For further differentiations and comparison see the work by Yvetta Kajanová, Kapitoly o jazze a rocku [Chapters on Jazz and Rock] (Bratislava - Ružomberok, 2003). 
creation of rock patterns the dotted rhythm is significant, the movement in triplets, and rhythms segmented into syncopes. These have come to rock music from European folk and stylized dances imported into country music, domesticated American salon music, rhythm and blues, and jazz.

\section{Structural Analysis of Rock Style Rhythms - an Example Es3 $^{93}$}

Continuing our research on rhythm and rhythmic patterns carried out between 1990 and $1998,{ }^{94}$ we endeavour to exemplify our idea about the unjustified usage of rock style designations in journalistic terminology; owing to their musical structure (rhythm, musical shape, improvisation, cover version) they do not always introduce new elements. The issue is more complicated as one and the same group may go through diverse styles in its development - from punk, via neopunk, gothic rock to alternative rock (The Cure, Siouxsie and the Banshees), or the same project is designated as soft rock or pop rock or adult pop (Peter Gabriel, Sting). Often different designations are used for the same style, e.g. art rock and progressive rock, alternative rock and indie rock, electronic rock or industrial rock.

The 1980s brought only a repetition of rhythmical patterns introduced by hard rock, art rock (progressive rock), punk rock and heavy metal in the previous development. The entrance of new wave and other styles in the early 1980s brought the repetition of rhythmical patterns - hard core, speed, thrash metal, alternative rock, including independent music, grunge, britpop, gothic, indie pop, glam rock, psychedelic rock, ambient, industrial rock, electronic rock, new age. Thus it is fair to say that a postmodernistic return to rock history in rhythms is realized only by the entrance of industrial rock, electronic rock and new wave. For transparency and easier orientation and separation of various "offshoots" it is necessary to allow for two criteria:

1. Criterion of historical authenticity, i.e. the relation to a particular period and provenance (the relation of a group or artist to a country and continent loses its relevance only in the present millennium, as the majority of these demonstrations have become part of global culture).

This study relate with the project VEGA 1/0728/11 and a monograph by Yvetta Kajanová, K dejinám rocku [A Contribution to Rock History] (Bratislava, 2010).

94 Yvetta Kajanová, "Improvizácia a jej rôzne podoby v jazze a rocku” [Improvisation and its Various Appearances in Jazz and Rock], in: Slovenská hudba [Slovak Music], vol. 20 (1994), p. 297-321. Yvetta Kajanová, "Rytmické archetypy v jazze a rocku ako kultúrny prejav negujúci 'národné' a smerujúci k 'univerzálnemu' " [Rhythmic Archetypes in Jazz and Rock as a Cultural Demonstration Controverting "the National" and Tending to "the Universal"], (Bibliotheca Musicae Neosoliensis, Zv. 3) in: Národné, individuálne a univerzálne prvky v hudbe [National, Individual and Universal elements in Music] (Banská Bystrica, 1998), p. 135-142. Yvetta Kajanová, Kapitoly o jazze a rocku [Chapters on Jazz and Rock] (Bratislava, 2003). 
2. Criterion of "hardness" (hard rock, heavy rock), accentuation of intensity, of tension in sound and rhythms as essential manifestations of rock, and "softness" in rock melodiousness and sound (mellow ${ }^{95}$ rock, light rock, easy rock, art rock, industrial rock, ambient).

The 1980s show the development towards the synthesis of various tendencies and styles in rock music. One line in rock has been developing through combinations of heavy metal and punk rock into speed metal, hard core, and thrash metal. A similar tendency to combine various styles may be observed also in the second rock line in electronic rock, new age (Enya, Enigma, Andreas Vollenweider etc.), alternative rock, soft rock (Peter Gabriel, Phil Collins etc.). The 1980s also brought polystylistic rock demonstrations in one album or project of a group. For instance, the work of the group Dream Theater (1985) extends to heavy metal style and progressive rock; the work of solo guitarists (Yngwee Malmsteen, Joe Satriani, Steve Vai etc.) dwells in polystylistic punk, experimental rock, progressive rock, heavy metal; the performance of Sade Adu has often been labelled as a mixture of rhythm and blues, soul, funky and soft rock and, although it has not much in common with jazz, from the beginning it has been especially attractive to jazz stages, where she performed and jazz literature owing to its unclassifiable substance.

All these tendencies following the "art rock" or "heavy metal" lines are distinguished to a great extent by unoriginal rhythms. Indeed the music of the representatives of these styles is not focused on bringing new rhythmical shapes, but on the combination of existing rhythms registered by rock history with rhythmic patterns of other genres. Their originality lies in discovering new sound and expression, while they utilize the space outside the 12-tone area, namely inharmonic sounds.

The synthesis in the "soft" rock hybridizes the genre; it is mixed with ethnic or jazz elements or elements of European music. For instance, for Sade it is Latin American music, for Enya Celtic and Irish folk music, guitarist Yngwee Malmsteen joins rock with European baroque, gothic rock groups mix industrial rock, punk rock and synthy pop. All these styles use syncopation, dotted rhythms, as demonstrations of dance character, and blues rhythms of Afro-American folk music.

\footnotetext{
Mellow - soft, sweet, luscious.
} 


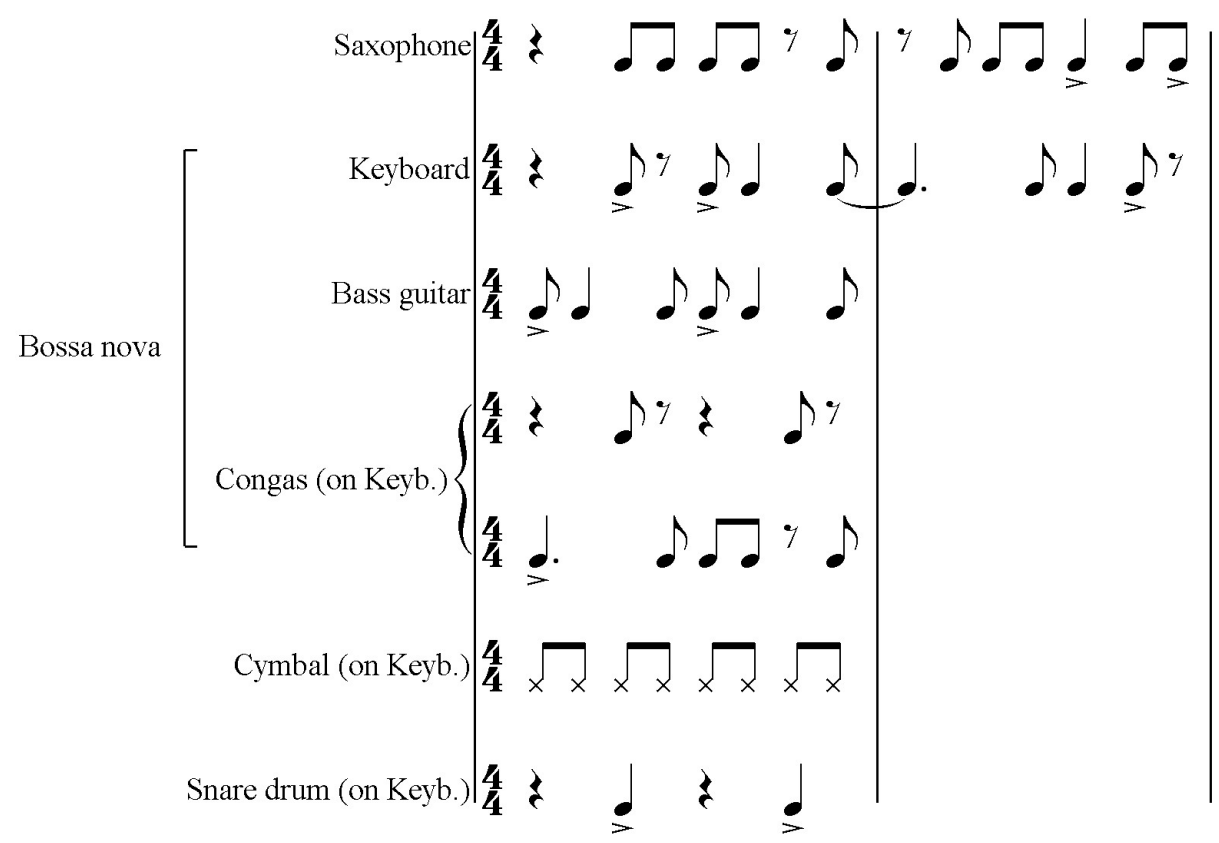

Example 1: Sade (Sade Adu/Ray St. John): Smooth Operator, LP Diamond Life, Epic 1984

The song in Example 1 (Sade) uses the Latino-American bossa nova rhythm. Several rhythmical lines are layered one on the other - they are part of the rhythmic section and create a pattern - imitation of percussion instruments on the synthesizers, all reminding us of electronic rock.

The synthesizers play the waltz rhythm (salon music from the nineteenth century) in Example 2, music by Enya, the representative of new age music. In Example 3 (Enya again), where different metrical changes are wrought by singing, the regular rhythm of the synthesizers reminds us of the style of industrial rock. Metrical changes come from Irish folk music. Other compositions in the Shepherd Moons album display regular rhythm, however, played rubato with various breaks and agogic changes. The periodicity of rhythm by which various metrical changes are accomplished is determined by singing similar to medieval Gregorian chant (in the song by Enya: How Can I Keep From Singing, LP Shepherd Moons, WEA, Warner Music 1991).

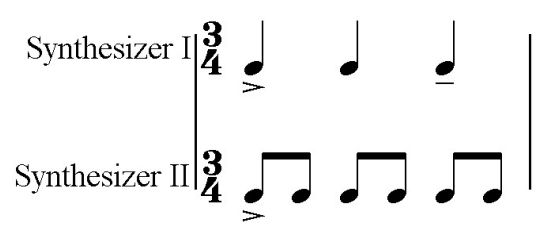

Example 2: Waltz pattern, Enya: Carribean Blue, LP Shepherd Moons, WEA, Warner Music 1991 


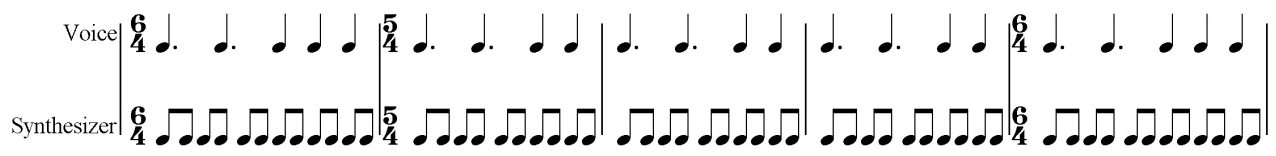

Example 3: Enya: Book Of Days, LP Shepherd Moons, WEA, Warner Music 1991

Alternative rock or pop rock as produced by the group U2 in the following example is rhythmically based on heavy metal music and hard rock. Nevertheless, the sound of the pattern is accentuated differently from hard rock; the sound of the cymbal fades away in the distance, the sounds of bass drum and snare drum dominate. The basic pattern originates from the joint rhythms of cymbal, snare drum and bass drum. From time to time guitar adds to the rhythmical section, or diminution of the beat into the sixteenth note occurs.

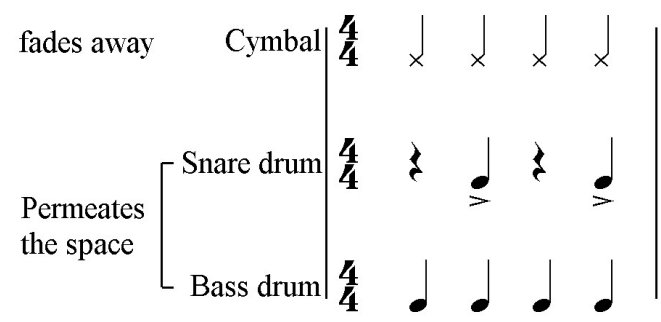

Example 4: U2: A Sort Of Homecoming, LP The Unforgettable Fire, Island 1984

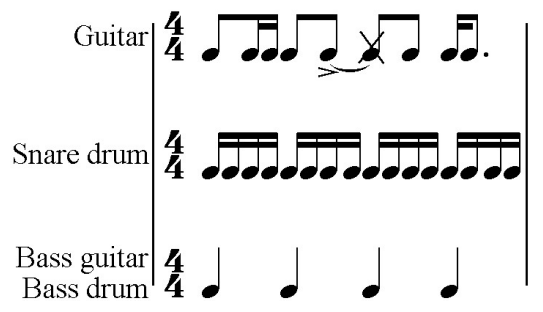

Example 5: U2: Bad, LP The Unforgettable Fire, Island 1984

U2 also use a typical rock pattern mostly used in hard rock, where it has generated polyrhythm.

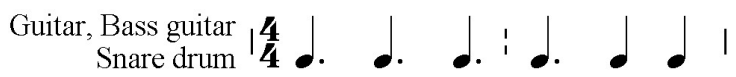

Example 6: U2: Promenade, LP The Unforgettable Fire, Island 1984 
Occasionally free rubato tempo appears with agogic changes (U2: 4th Of July, LP The Unforgettable Fire, Island 1984), or sections lacking any pattern, any regular rhythm, focused on sound used by art rock musicians previously.

Gothic rock has tried mimic punk articulation in singing with the sound of pop music and with the use of synthesizers. Thus it has come closer to pop music in terms of the production of hits and techno and synth pop styles. In rhythm the particular lines are layered, which may be found also in electronic rock and techno style. Diminution of rhythm in gothic rock utilizes more abundantly the complementarity of patterns in quarter notes, sixteenth notes, eighth notes and breaks than in electronic rock. The group Siouxsie and the Banshees was founded in 1976 as a punk rock group; then various stylistic changes occurred from postpunk to gothic and alternative rock. This alternation of eighth notes with sixteenth notes evokes ethnic rhythms, the pattern structure reveals the accentuation of the first and third beat, and the diminution of the rhythm into the sixteenth notes indicates the origin of a new structure.

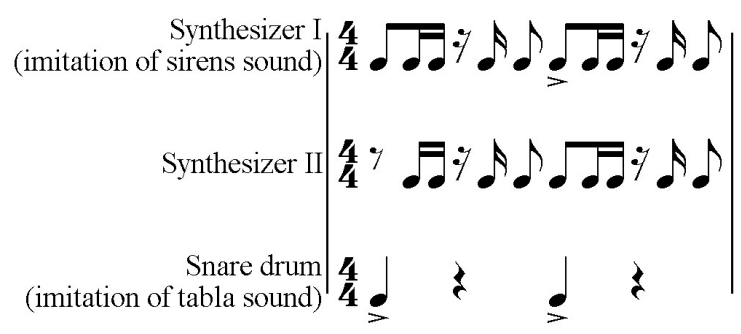

Example 7: Siouxsie and the Banshees (The Sherman Brothers): Trust In Me, CD Through The Looking Glass, Polydor 1987 (album of alternative rock Through The Looking Glass includes also cover versions of other authors)

A new structure illustrated in Example 8 demonstrates the new pattern in timpani part.

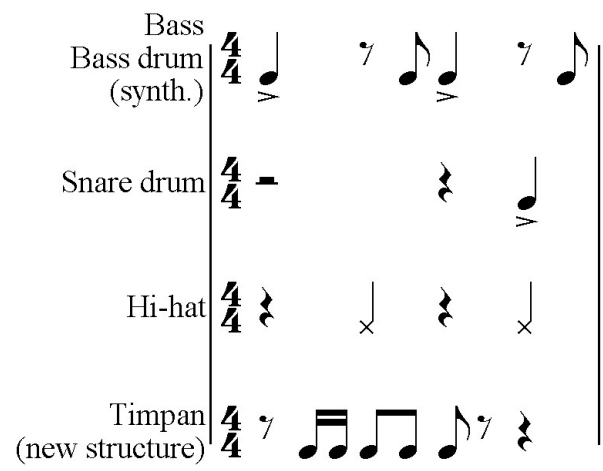

Example 8: Illustration of alternative rock music pattern, Siouxsie and the Banshees: Drifter, LP Superstition, Polydor 1991 
In alternative rock composition reggae rhythm may occur, which we can see between the guitar and snare drum in Example 9.

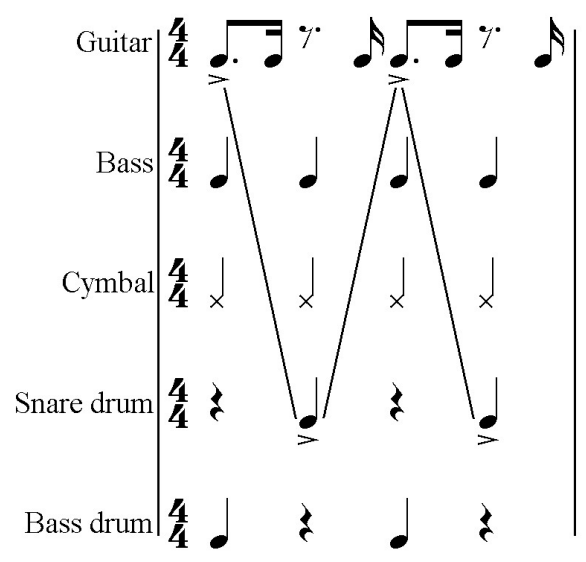

Example 9: Siouxsie and the Banshees (Iggy Pop/Ricky Gardiner): The Passenger, CD Through The Looking Glass, Polydor 1987

In Example 12 The Cure: Icing Sugar pattern has been changed to typical rock pattern in the second measure. The syncopated part of this pattern is a diminution (see Example 11) of the typical rock pattern. It means, that the typical rock pattern (see Example 10) returns to the alternative rock, but in modified structure. This modified pattern may be found in Example 12.

\section{4 d. d. d ।}

Example 10: A typical rock pattern

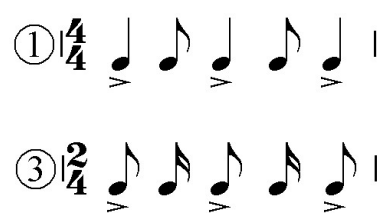

Example 11: A variation of the typical rock pattern and its diminution

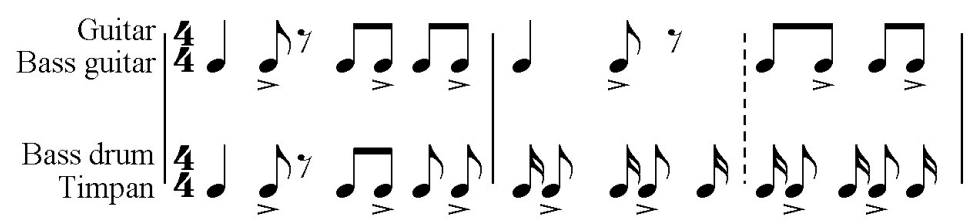

Example 12: Modified rock pattern, The Cure: Icing Sugar, CD Kiss Me, Kiss Me, Kiss Me, Fiction 1987 
Solo guitarists (Yngwee Malmsteen, Joe Satriani, Steve Vai) usually take over rhythmical patterns from hard core, speed metal, heavy metal and employ a complementarity of patterns, which occurs between the bass and snare drum or other instrument. The task of the guitar is either to play a basic melodic-rhythmical motif while building the composition as in heavy metal or it plays solo. A reliable basis for its solo part is created by percussion instruments and bass guitar, the patterns and improvisation of which approach the jazzrock of the 1970s and 1980s. In this case the bass guitar uses a technique of slap bass. In Example 13 groove is used in the bass guitar, the cymbal plays a pattern of jazz style "bop", the bass and snare drum accentuate either the third beat or the second and fourth ones, as in many hard rock compositions.

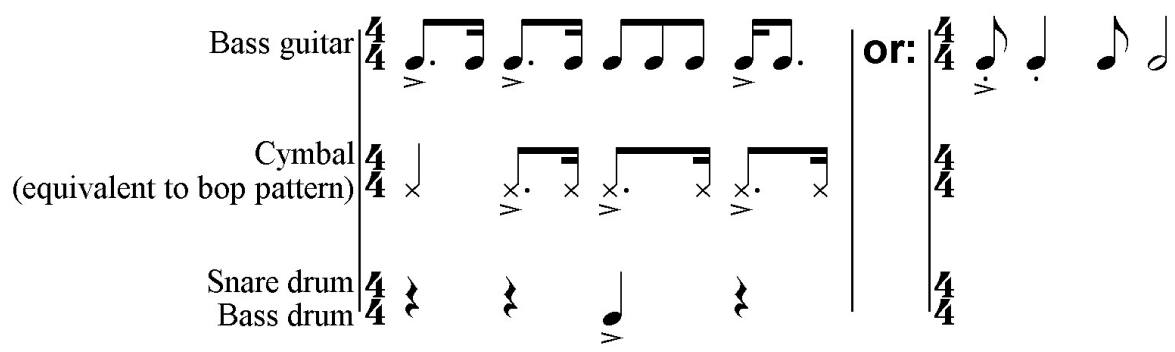

Example 13: Steve Vii: Erotic Night Mares, CD Passion and Warfare, Relativity/Epic 1990

In polystylistic rock music - alternative rock, indie rock, instrumental rock - the typical rock patterns return. Accents are usually either on the first and third beat or the second and fourth ones. All presented examples emerged in the crystallized hard rock period of the late 1960s. The following are the typical rock patterns:
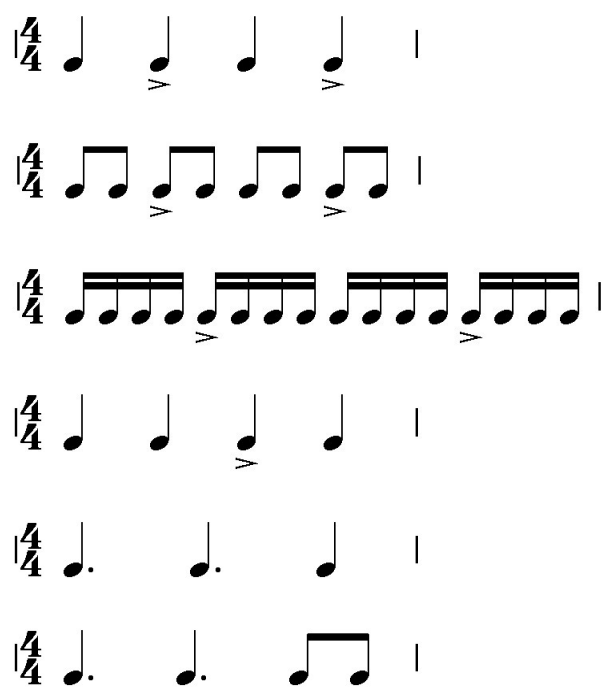

64 


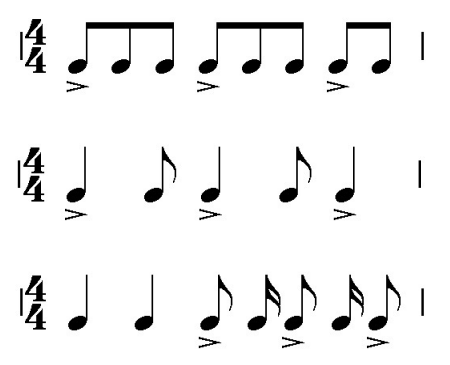

Example 14

\section{Conclusion}

Rock musicians seem to be experts of their own history, especially from the eighties to present time. They created new rhythmic patterns by combining different rock styles which opened the new polystylistic possibilities for rock music. Rock moved to a new period seemingly looking as stagnated period, however observed examples illustrate how new rhythmic structures can develop from the previous rock styles by adding new ideas. Therefore, stagnation of rock music is not relevant.

\section{Rhythmus und die polystilistische Rockmusik}

\section{Zusammenfassung}

Der Beitrag bietet eine kurze Präsentation der Arbeit der Autorin an, die sich in den letzten zwei Jahrzehnten der Problematik des Rhythmus in der Jazz- und Rockmusik widmet. Sie geht davon aus, dass es im Jazz und Rock in den einzelnen Perioden der Geschichte bestimmte rhythmische Modelle gibt. Die Patterns im Rhythmus bilden die Grundlage für die Existenz des Stils im Jazz und Rock. Relaxgefühl ist typisch für die Jazz Rhythmen, die aus der Tradition der Folkmusik in Afrika quellt.

Die Rhythmen sehen als komplizierte Poly-Rhythmen aus, mit einer betonten und einer unbetonten Silbe des Taktes - Beat und Off Beat in der Jazz Geschichte. Die Rock Patterns sind dagegen durch Essenz der städtischen Musikkultur gekennzeichnet, „die die Härte“ der Ära hervorhebt. Für die beide Genres (Jazz und Rock) gilt, dass Sie im Gegenteil zu der europäischen Musik entweder die zweite und vierte oder dritte und erste (die Dritte ist stärker akzentuiert) Silbe des Taktes akzentuieren, wobei die restlichen Taktsilben nicht akzentuiert werden (Prinzip des Off Beats gegenüber dem Beat).

Die Autorin befasst sich auch mit der genaueren Strukturalanalyse der Rock-Patterns. Anhand dieser zeigt Sie auf die Mischung der Rock-Stils in der postmodernen Periode 
solchen Darsteller wie Steve Vai, Siouxsie and The Banshees, The Cure, U2, Enya oder Sade hin. Dabei ist es nicht klar welchen Stil diese Künstler eigentlich repräsentieren. In der Musik mischen sich Begriffe wie Alternativ-Rock, Gothic-Rock, Indie-Rock, HardCore, Speed-Metal, Heavy-Metal und Soft-Rock. An den konkreten Beispielen beweist Sie den Rückkehr von typischen Rock-Rhythmen in der Form des Alternativ-Rocks und polystilistischen Rockmusik seit 80-er Jahren bis zu Gegenwart.

\title{
Rytmus a polyštýlová rocková hudba
}

\begin{abstract}
Resumé
Príspevok prináša krátku ukážku práce autorky, ktorá sa v priebehu dvoch dekád zaoberá problematikou rytmu $\mathrm{v}$ jazze a $\mathrm{v}$ rockovej hudbe. $\mathrm{V}$ zásade vychádza $\mathrm{z}$ predpokladu existencie rytmických modelov $v$ jednotlivých historických obdobiach $\mathrm{v}$ jazze a v rocku, ktoré ich kreujú ako esenciálne štýly. Pre jazzové rytmy je charakteristický relaxačný pocit, vychádzajúci na jednej strane $\mathrm{z}$ tradície africkej l’udovej hudby, ale na druhej strane prezentujúci sa v zložitosti polyrytmov v chápaní l’ahkej a tažkej doby - beatu a off beatu v jazzovej tradícii. Rockové patterny sú na rozdiel od jazzu poznačené esenciou mestskej hudobnej kultúry, zvýrazňujúcej „tvrdost““ doby. Pre oba žánre jazzu a rocku platí, že na rozdiel od európskej hudobnej kultúry (artificiálna hudba) akcentujú druhú a štvrtú dobu alebo tretiu dobu, pričom na ostatné pripadá l'ahká doba (off beat voči beatu). Ďalej sa zaoberáme podrobnejšou štrukturálnou analýzou patternov v rocku, prostredníctvom ktorých poukazujeme na miešanie rockových štýlov v období postmoderny takých predstavitel'ov ako Steve Vai, Siouxsie and The Banshees, The Cure, U2, Enya, Sade, kde nie je jasné, aký štýl vlastne reprezentujú a miešanú sa tu pojmy alternatívny rock, gothic rock, indie rock, hard core, speed metal, heavy metal a soft rock. Pokúšame sa na konkrétnych príkladoch doložit návrat typicky rockových rytmov, ktoré sa najčastejšie objavovali v období od rock and rollu, cez hard rock, art rock včítane punk rocku.
\end{abstract}

\section{Keywords}

Rock; pattern; style; rhythm; polystylistic rock music; alternative rock; indie rock.

\section{Schlüsselwörter}

Rock; Motiv; Stil; Rhytmus; Polystilistisch Rock Musik; Alternative Rock; Indie-Rock. 